\title{
ARTE E SUBJETIVIDADE: a constituição do sujeito
}

\author{
Geraldo Aparecido Ferreira Júnior ${ }^{1}$ \\ Leonardo Carrijo Ferreira ${ }^{2}$
}

\section{RESUMO}

INTRODUÇÃO: Sabe-se que a arte está evidente no cotidiano de cada ser, sendo, a mesma, uma forma de permitir que o sujeito se expresse e se identifique com um grupo, uma cultura, e comunique sua subjetividade a fim de encontrar similaridades e empatia. Há uma necessidade de afirmar como a arte contribui para o encontro do indivíduo consigo e com os outros. Arte é algo universal, sendo ela interpretada de acordo com a cultura, experiência e visão que o sujeito tem sobre o mundo. Nela o indivíduo pode expressar seus sentimentos e emoções. É por meio da arte que o ser humano se comunica com o seu interior e, também, consegue atingir outras pessoas, auxiliando-as nessa comunicação com o íntimo. A subjetividade, tratada neste estudo, possibilita que o indivíduo tenha suas particularidades, seja na constituição das funções psíquicas, da consciência, da ação ou da personalidade. A troca entre o que é interno e externo é necessária para que a subjetividade seja desenvolvida. Em resumo, subjetividade é o procedimento de transformar aquilo que é universal em algo singular, único para o sujeito. OBJETIVO: O estudo tem como objetivo apontar e refletir sobre a importância das artes na construção do sujeito, tendo em vista o processo de criação, percepção e como eles influenciam na constituição da subjetividade do mesmo. MÉTODO: O desenvolvimento do estudo se deu por meio de pesquisa bibliográfica. Utilizou-se base de dados na internet como: Scielo, Biblioteca Digital USP e ferramentas de pesquisa como o Google Acadêmico. Foi realizada a pesquisa através da combinação de termos como: arte, subjetividade, teatro, construção do sujeito, processo de criação. RESULTADOS: Como resultado, observou-se que as artes como: teatro, música e artes plásticas possibilitam ao sujeito o encontro consigo mesmo, ou seja, um sentido de vida. Com isto, pode, da mesma forma, permitir novas perspectivas e a potencialização de sua subjetividade. Por intermédio

\footnotetext{
${ }^{1}$ Acadêmico do curso de Psicologia da Faculdade Patos de Minas - FPM. E-mail de contato: g.junior.jr@hotmail.com

${ }^{2}$ Mestre pela Universidade Federal de Uberlândia - UFU - e docente do Departamento de Graduação em Psicologia da Faculdade Patos de Minas - FPM.
} 

das artes, foi exposto que elas são apropriadas para atingir o indivíduo em seu âmbito cognitivo, são capazes, também, de impulsionar o desenvolvimento de aspectos criativos, sentimentais, emocionais e corporais, possibilitando ao sujeito que entre em contato com seu interior e, também, atinja outras pessoas por meio de sua expressão artística. A arte possui uma característica peculiar que possibilita a identificação de um objeto externo e o torna subjetivo, possibilitando diferentes sentidos a cada nova leitura. CONSIDERAÇÕES FINAIS: As artes presentes no cotidiano de cada indivíduo possibilitam que o mesmo possa concretizar algumas de suas características mais subjetivas.

Palavras-chave: Arte; Teatro; Subjetividade; Psicologia. 